\title{
Biopolitics and the regulation of vulnerability: the case of the female trafficked migrant ${ }^{*}$
}

\author{
Sharron A. FitzGerald \\ Institute of Geography and Earth Sciences, Aberystwyth University
}

\begin{abstract}
This article interrogates the connections between normativity and geographical space. Specifically it focuses on the biopolitical discourses that operate around the idiom of the vulnerable female trafficked migrant in the United Kingdom. The article's structure and argument question how state parties frame the notion of female vulnerability as a distinct biopolitical category. I argue that this process produces and sustains the perceived need for biopolitical regulation of the national community. I question how the state's regulation of the bodies and behaviours of female trafficked migrants is entangled with anti-immigration agendas that aim to extend the power of the state extra-territorially.
\end{abstract}

\section{Introduction}

This article interrogates how the neoliberal state frames the notion of female vulnerability as a distinct category of meaning that is part of the emerging geographies of the neoliberal state. In particular, it focuses on how the neoliberal state's normative attempts to regulate the female trafficked migrant's mobility are entangled with domestic anti-immigration agendas. ${ }^{\mathrm{I}}$ In order to address these issues, I present an alternative conceptual rubric to understand how the state reframes human trafficking, and the attendant issue of trans-border sex work as a security issue. In particular, I argue that increased internationalism has provided the state with new spaces to regulate the mobility of female trafficked migrants. Specifically, I assert that the state's preoccupation with protecting vulnerable migrant populations intersects with neoliberal biopolitics that underpin the 'right to belong' to the nation-state (Huysmans, 2006).

Focusing on these normative geographies raises interesting questions about the often-lamented unbundling of the sovereign power of the nation-state (Benhabib, 2004). Thus, in this article I argue that processes of globalisation facilitate new and emerging geographies of governmentality reflected in (and constructed by) the biopolitics of managing populations (Legg, 2005; Cunningham, 2008). In order to develop the link between the state's attempts to regulate the vulnerable female trafficked migrant and the normative biopolitics of 'society that must be defended', I use Michel Foucault's theorisations of governmentality in his College de France Lectures (Foucault, 2003, 2009). Finally, at a more applied level, I take the United Kingdom as a case-study to explore how the state's concern with securitisation intersects with the biopolitics of protecting the female trafficked migrant.

* With the usual caveats, I wish to thank Mary Ewert for her help with this article. This article would not be possible without the feedback I received from colleagues and friends at the Critical Legal Conference in Leicester 2009. Thanks also to the Critical and Cultural Politics group, Department of International Politics, Aberystwyth University for their engagement and insightful comments on an earlier draft. Finally, I wish to thank my two anonymous referees for their suggestions.

I Contemporary socio-legal scholarship defines normativity as encompassing the 'formal' arena of laws, regulations and policies (Fineman and Thomadsen, I99I; Cooper, 2004), but also the 'informal' world of norms and mores, expectations and ideals that shape particular practices of thought, speech and action (Honig, 200I; Butler, 2005). 
To pursue this debate, I engage with two interconnected government documents: the Home Office's 2002 White Paper Secure Borders, Safe Haven: Integration with Diversity in Modern Britain (hereafter referred to as Secure Borders), and the 2006 UK Action Plan on Tackling Human Trafficking (hereafter referred to as The Action Plan). To begin this investigation, I contextualise the problematic within feminist interdisciplinary literature on the relationship between women, the state and mobility.

\section{Vulnerability, the state and women on the move}

The question of how to understand and conceptualise the relationship between the state, normativity and the everyday lives of women has long been the focus of feminist attention (MacKinnon, I989; Young, 1990). Initially, feminists focused on the need to include women's experiences in debates on the state. Scholarship addressed the patriarchal structure of the nation-state system where commentators observed that this political structure legitimised inequality between men and women (Barry, I979; Pateman, I988). Consequently, feminist demands for formal equality between the sexes rejected any notion of special treatment for women. Such classification, they argued, invariably legitimised gender difference on the basis that it exacerbated inequalities between the sexes (Wallach-Scott, I999; Yuval-Davis, Anthias and Kofman, 2005).

More recently, feminist critiques of the neoliberal state have attempted to move beyond this equality/discrimination model to produce a more nuanced account of the differentiated discourses and practices that both create and sustain women's vulnerability (Beasley, I999; Fraser, 2007). Consequently, feminist intersectional analyses of women's vulnerability have proliferated (Crenshaw, Gotanda and Peller, I995; Eisenstein, 2004). Feminists observe that vulnerability is a fundamental aspect of the human condition, mediated by categories such as ethnicity, sexuality and class. Thus, the state and juridical systems incorporate discourses of gender difference into their treatment of women, thereby perpetuating their socioeconomic and political marginalisation (Nussbaum, 1999). Such an understanding of vulnerability, they argue, ought to be a central component of all policy initiatives (Butler, 2005; Fineman, 2008). In regard to feminist socio-legal scholarship, researchers have undertaken intersectional work on the dynamics of law and women's vulnerability in relation to citizenship, sexual and human rights (Charlesworth and Chinkin, 2000; Cooper, 2004; Grabham and Hunter, 2008). There is now a wide feminist literature on women's reproductive and sexual rights (Bottomley and Conaghan, I993; Lacey, I998; Fletcher, 2005), and the impact of gendered and racialised disciplinary practices on women's bodies (Smart, I989; Bridgeman and Millins, 1995; Askola, 2008; Munro and Della Giusta, 2008). This, in turn, led to feminists petitioning the state to take seriously women's vulnerability in the 'private' domain, especially in relation to violence of all kinds (Crenshaw, I994; Cornell, I998; MacKinnon, 2006).

Human trafficking and the attendant issue of trans-border sex work, as a case-study, offer an opportunity to highlight the normative discourses through which the neoliberal state manipulates the concept of female vulnerability. For the past twenty-five years, deeply entrenched ideological and political positions on sex work have divided feminist responses to these issues. On the one hand, the pro-sex worker lobby advocate for women's agency and the right to bodily integrity (Kempadoo, I999; Goodey, 2002; Sullivan, 2003; Doezema, 2005, Augustin, 2007). On the other hand, the anti-sex work lobby view sex work as evidence of a continued culture of patriarchal violence against all women (Barry, I995; Hughes, 2002). This schism has resulted in circular argumentation, and it has prevented feminists from developing appropriate anti-trafficking policy recommendations.

One of the unintended consequences of the divisive nature of feminist theorisations and advocacy on human trafficking is that it has reduced many non-Western women to 'suffering bodies in need of protection by the law and the state' (Miller, 2004, p. 27), rather than as people who require participation and equality. In recent years, as Western liberal democracies have become more 
sensitised to gender equality and discrimination, human trafficking has come to represent an issue that encompasses the abuse of geo-specific populations of women (Dustin and Phillips, 2008). This targeting of non-Western women also coincides with law and social policy in the European Union that 'targets migrant women for sexual exploitation' (Askola, 2008, p. 204). Important here is that this rendering of human trafficking eschews all other forms of labour exploitation (FitzGerald, 2009). The problem with this framing of human trafficking is that it goes hand in hand with very limited anti-trafficking initiatives. These initiatives use racialised and gendered interpretations of female vulnerability to rescale state attempts to manage the mobility of specific populations domestically and internationally. Legg (2005) observes that rescaling occurs through the state's ability to influence 'ways of seeing and representing reality' and through 'techniques and technologies of government' that intervene 'in reality through strategies and procedures' (p. I48). Of particular interest in the context of the argument in this article, is how official ways of seeing and representing geo-specific populations of women as vulnerable provides the state with a rationale for a series of exclusionary tactics intended to keep geo-specific populations out of Europe (Samers, 2000).

Discussing how this process operates in the UK, Moira Dustin and Anne Phillips (2008) observe that one of the salient themes that defines the UK's commitment to gender equality 'is a greater willingness to challenge practices represented as oppressive to women in the developing world, even if they are authorised by religion and culture' (p. I468). They note that this trend in the UK's law and social policy is informed by 'a shift from a shallow but widely endorsed multiculturalism to a growing preoccupation with abuses of women in minority cultures' (Dustin and Phillips, 2008, p. 407). Elsewhere, Vanessa Munro (2005) observes that the UK policies to protect female trafficked migrants have become intertwined with normative social and cultural mores about 'appropriate' female sexual behaviour, and deeper value judgements about prostitution. She remarks that 'at the design and implementation stage of a domestic anti-trafficking response within the UK are key ideological perspectives on the moral and legal status of prostitution' (Munro, 2005, p. IOI). Under New Labour, prostitutes emerge as 'a vulnerable sexual minority' (Sander and Campbell, 2007, p. 3) in need of state protection. In a discursive shift that exemplifies the rescaling of normative discourses of female vulnerability, the UK government tends to conflate prostitution with human trafficking and assumes that all female trafficked migrants are coerced into the sex industry (Askola, 2008).

Discursive strategies, such as these, eschew difference among women because they are based on a false reciprocity of values that assumes that all women share the same understanding of their vulnerability (Kapur, 2005). Furthermore, such polices perpetuate an essentialised view of female trafficked migrants as naive and helpless, a view that denies their agency and right to selfdetermination (Scoular and O'Neill, 2007; FitzGerald, 2009). Such a figuring of human trafficking cannot accommodate the finer scales of ambiguity that characterise the status of these women in international migration circuits. To exemplify, female trafficked migrants often start their journeys as willing agents in specific places that are connected to processes of globalisation at a variety of scales (Askola, 2008). Sometimes they become victims; at other times they occupy places in between (Augustin, 2005). A continuing weakness in feminist theorising on human trafficking and sex work is that concepts like vulnerability, migration, globalisation, regulation, rights and normativity remain on the abstract level of the state, the EU or law. As a result, we continue to fail to uncover the worlds where national and global forces connect to construct racialised and gendered images of vulnerable female trafficked migrants. I want to argue that it is time to complement the abstract and the hypothetical thinking in law, philosophy, political science and cultural studies with a spatial framework to understand the new geographies of governmentality. Such a rubric has the possibility to bring the abstraction often associated with issues like vulnerability literally 'down to earth'. 
To address these lacunae and to begin this conversation, I turn to feminist geographical scholarship to explore the state's attempts to deploy notions of female vulnerability to extend its power extra-territorially. Researchers have focused on challenging canonical understandings of the scale of territorial power of nation-states (see e.g. Moutz, 2004; Silvey, 2006), its boundaries as an embodied geopolitics of refugee movement and immigration control (see, e.g., Hyndman, 2000; Perrons, 2004; Walton-Roberts, 2004), spaces of citizenship and the state regulation of national territory and sovereignty (see Staeheli, Kofman and Peake, 2004; Kofman, 2005). Of particular interest, in the context of the current article, is geographical work that interrogates how the state uses power relationships at the scale of the body to regulate the body politic (Nagar, Lawson, McDowell and Hanson, 2002). Most important is the geographer's concern with revealing 'the spatialised processes through which state practices materialise in relation to migrants' (Moutz, 2004, p. 328). Feminist political geographers have argued that in the contemporary moment we are witness to a resurgence of a new racialised and gendered politics of exclusion (Riaño and WastlWalter, 2006). Such politics of exclusion nurture moral panics about hordes from the global south (Staeheli et al., 2004; Perrons, 2004). The trafficked migrant embodies those populations who transgress political borders. In short, the trafficked migrant is the visible evidence of those 'leaky borders' (Gilbert, 2007, p. 77) that support state rhetoric on the need for stricter immigration law and border control.

Yet human trafficking and trans-border sex work reveal a fundamental gap in mainstream geographical research. Hubbard, Matthews and Scoular (2008) remind us that, as a rule, geographers have tended to avoid sustained critical explorations of sex work and human trafficking, and their broader applications in state-formation. Where geographers make mention of prostitution, it tends to focus on either the economic, criminal and spatial distribution of prostitution in Western cities (Henderson, I999; Kumar, 2005) or the regulation of sexuality and the politics of empire (Phillips, 2006). This criticism is important because it reinforces the need for feminist geographers to view the state's concern with the female trafficked migrant as an embodied space of regulation. Yet I do not reject this scholarship. Rather I argue that by combining the geographer's multi-scalar and context-driven approach to migration, the state and geographical spaces of prostitution with feminist socio-legal scholarship on normativity, we have a rubric to explore the new and embodied geographies of neoliberal governmentality. I believe that we can amplify the dimensions of the state's biopolitical regulation of geo-specific populations of women by engaging with Michel Foucault's Collège de France Lectures.

\section{Biopolitical governmentality}

While Foucault's main thesis on biopolitics is hardly new, I have found that his conceptual tools can be put to new and expansive uses in my research on human trafficking. It is one of the key lessons of Foucault's analysis of the genealogy of the modern state that 'the survival and limits of the state should be understood on the basis of the general tactics of governmentality' (Foucault, 2003, p. I09). In this account, the state does not achieve its legitimacy through territoriality alone, but by using the human body as another critical site of control (Hannah, 200I). In this context, governmentality works on and through the body and constitutes Foucault's understanding of biopolitics (Legg, 2005). In this reading, governmentality names 'the micro-powers' of biopolitics that not only constitute a particular regime of power, but 'the ways in which one conducts people's conduct' (Foucault, 2003, p. I92). In his 1975-1976 Collège de France Lectures, Foucault elaborates his reading of biopolitics to encompass not only class divisions, but also colonialism, racisms and behaviours of all kinds 'as a way of separating out the groups that exist within a population' (Foucault, 2003, pp. 254-55). Foucault's theory of governmentality operates through knowledge about certain populations 'in order to guarantee the process through which the state could be 
secured and the population could be made productive' (Legg, 2005, p. 245). Viewed in this way, biopolitics is the manifestation of a distinctly racialised form of state regulation of 'Others' (Philo, 2000; Rose and Osborne, 2004). In this figuring of power, the state regulation of receiving and migrant populations constitutes biopolitics.

Foucault extends this debate in his 1977-1978 series of lectures, Security, Territory, Population (Foucault, 2009). This led him to identify biopolitical governmentality as ways of producing knowledge and certain discourses that become internalised by individuals, and that guide the behaviour of populations (Legg, 2009). This, he argues, leads to more efficient forms of social control, as knowledge enables individuals to govern themselves. Foucault places the question of population and the liberal political economy at the centre of 'forms of normalisation peculiar to security' (Foucault, 2009, p. 397). By broadening out of the scale of his theorisation, Foucault directs us into new conceptual spaces such as security, the national economy and national identity politics where we can identify the different spaces where biopolitical regulation extends the power of the state territorially and ideologically (Buonfino, 2004). As I discuss below, a spatially sensitive reading of these processes helps to unpack the multiple embodied sites where individuals such as immigration officers and trafficked migrants themselves participate in the biopolitics of 'society that must be defended'.

Feminist critique of Foucault's lack of attention to gender is well-documented (Alcoff, I994; Smith, 1999). Yet I do not reject his theorisations. Rather I suggest that combined with feminist interdisciplinary theory, Foucault's concept of biopolitical regulation of populations extends to my interrogation of the state manipulation of human trafficking to address issues of higher political importance such as security. Many of the above points are borne out in the neoliberal state's representation of both the generalised and particular vulnerability of geo-specific populations of women to trafficking. However, a key aspect of this strategy is that 'anti-trafficking programmes have been absorbed into state security agendas which tend to prioritise surveillance, immigration controls and border controls over human rights' (Sullivan, 2010, p. 99). Since trafficking networks often originate in non-EU territory 'this has made (very) remote control all the more necessary for security-minded member governments and specific EU institutions' (Samers, 2000, p. 30). In this respect, it becomes possible to argue that state discursive practices have racialised and gendered consequences because they produce and sustain a strategic concept of vulnerability as another avenue of state-formation. In the concluding section of this article, I map how such discursive strategies operate in UK anti-trafficking measures as part of a broader debate on securitisation.

\section{Mapping the biopolitics of human trafficking in the UK}

Turning our attention to the UK context, I argue that the normative agenda that emerged in the wake of the $200 \mathrm{I}$ race riots in the north of England towns of Bradford, Burnley and Oldham exemplify the rescaling of the biopolitics of governmentality. Much of the violence in $200 \mathrm{I}$ occurred between white British men and newly arrived migrants. Commentators attribute the conflict to 'the social deprivation experienced by the minorities and the majority in those areas' (Schuster and Solomos, 2004, p. 282). Fundamentally, these differently situated groups contested each other's right to belong to the nation-state. Responding to the events in the north of England, in 2002 the UK government published a White Paper, Secure Borders.

The White Paper triggered heated dialogue among scholars, politicians and activists in the UK and internationally (Young, 2003; Schuster and Solomos, 2004; Kapur, 2005). For example, Young (2003) notes that the document called for a return to 'a mono-racial, culturally uniform British identity in which non-white people's presence is tolerated - and even then only conditionally' (p. 449). Other commentators note that after he became Home Secretary, David Blunkett, had 
'been engaged in finding ways to establish a "sense of belonging" to the British national collective as a pre-condition for gaining formal British citizenship' (Yuval-Davis et al., 2005, p. 526). Clearly, in Secure Borders this preoccupation influences the Home Secretary's statement:

'The reports into last summer's disturbances in Bradford, Burnley and Oldham ... signalled the need to foster and renew the social fabric of communities, and rebuild a sense of common citizenship.'

(HMSO, 2002, p. II)

Yet, instead of tackling these issues head on, Secure Borders illustrates how there is a growing tendency to mobilise them within 'a domain of insecurity' (Huysmans, 2006, p. 4). An important implication of this strategy is that it operates with the aim of reframing migration. It is possible to make a connection here between Foucault's (2009) theory of biopolitical governmentality that works on and through bodies, and the individual's responsibilities through a devolved form of citizenship. An instructive example of the micro-powers of biopolitics is the Home Secretary's insistence that in order to tackle this issue:

'The government will initiate an open and constructive debate about citizenship, civic identity and shared values. It is only through having such a debate that we will have the basis for bringing together people of different races, cultures and religions in a cohesive society.'

(HMSO, 2002, p. II)

Within this biopolitical framing of managing domestic and foreign populations in terms of 'the civic and political dimensions of British citizenship' (HMSO, 2002, p. I2), the government situates external processes of globalisation and international migration as threats to the nation.

To give some further examples of this devolved biopolitics of state-formation that works on and through the bodies of citizens, in Secure Borders David Blunkett asserts that the unrest in the north of England reflects how the 'ease of [international] movement has broken down traditional boundaries' (HMSO, 2002, p. 3), and thereby it destabilises the nation's security capability. More specifically, he argues that increased international migration had left Britain a country that is full of 'fractured and divided communities, lacking a sense of common or shared civic identity to unite around' (HMSO, 2002, p. II). Informative in the context of the biopolitics of state-formation and national identity politics is his assertion that:

'[O]ur domestic and social policies in relation to nationality, immigration and asylum application must therefore respond both to the reality beyond our borders and the danger posed by well meaning but indecisive drift at home.'

(HMSO, 2002, p. 27)

Hence, an important element of Secure Borders is a discursive reliance on the notion of an embodied and territorially grounded biopolitics that taps into public anxiety about migrants and the loss of national identity (Benhabib, 2004). The government reinforces this framing in the White Paper by suggesting that British identity is vulnerable to external threat. It is in this landscape of security and cultural threat that the state identifies the vulnerable female trafficked migrant as representative of those populations that challenge the integrity of the nation - morally, ideologically and politically thereby revealing the dangers of our leaky borders.

The vulnerable female trafficked migrant poses a particular challenge to how Secure Borders frames migration controls, and its ability to tackle illegal migration at source (Kapur, 2005). As elsewhere, in official discourses the link between sex work and trafficking is strong:

'We intend to bring forward wide-ranging changes to the law to deal with trafficking for commercial sexual exploitation both domestically and internationally... we are determined to close the loophole that allows foreign and EU nationals of whatever sex or age to be brought to the UK for the purposes of sexual exploitation.'

(HMSO, 2002, p. 85) 
Whilst the Home Office refers to both men and women as vulnerable to traffickers, it is clear that the government continues to view women to be 'at far greater risk of being trafficked then men, particularly for sexual exploitation' (HMSO. 2002, p. 90). This meta-narrative of one type of female trafficked migrant is problematic. We can understand the problems associated with this concept if we recognise that racialised and gendered signifiers of vulnerability structure UK responses to human trafficking and trans-border sex work. In Secure Borders, trafficked migrants become what Foucault (2009) conceived as 'the subjects of right over whom political sovereignty is exercised [and] appear themselves as a population that a government must manage' (p. 24). Within this figuring, vulnerability emerges as a discourse that justifies the state practice of 'juxtaposed control' (HMSO, 2002, p. 95) or 'external policy' on securitisation that exists across all EU jurisdictions in order to exclude unwanted migrants 'for their own good' (Samers, 2000, p. 38).

An important element of the state's case for increased securitisation in the UK is its discursive reliance on women's embodied vulnerability to foreign organised crime gangs (Munro, 2005; FitzGerald, 2009). Examining Secure Borders we can see how this reading of women's vulnerability permits the state to retrieve older racialised and gender stereotypes of traffickers 'who use the misery of others for their own gain' (HMSO, 2002, p. 6). Consider the following:

'[T]hose who can truly be described as trafficking victims have usually been treated as little more than a commodity. The exploitation may take the form of bonded labour... that violate their legal or human rights. It may be commercial sexual exploitation.'

(HMSO, 2002, p. 76)

This framing of human trafficking does important discursive work in terms of preparing the groundwork for institutionalising spatial distancing as an appropriate response to this issue. This occurs by perpetuating the notion that all traffickers are non-Western men. This is illustrated by the Home Secretary's assertion that 'the most abusive forms of it [trafficking] ... are more prevalent outside the UK' (HMSO, 2002, p. 90).

Kapur (2005) notes that in the UK the male 'Other is regarded as a violator of rights and the British cultural standard as the civilised measure against which the cultural Other must be assessed' (p. I56). Thus, Secure Borders deploys colonial discourses of 'rescue' and 'rehabilitation' of female trafficked migrants. Miller (2004) notes that state parties are slow to acknowledge that trafficked migrants are 'citizens entitled to rights and social justice, as opposed to utterly helpless victims in dire need of rescue' (pp. 30-3I). Laura Augustin (2007) comments that such racialised and gendered accounts of trafficking eschew the fact that women often play key roles as recruiters or managers in trafficking networks.

Important for the purposes of this paper is how Secure Borders justifies maintaining spatial distance between unwanted migrants and the receiving populations based on the premise that trafficking women is anathema to British cultural and moral values. In this context, the connections between biopolitics, national identity, human trafficking and normative spatiality come into sharp relief. Here, it is worth returning to Anne Phillips's (2007) contention that the UK government's treatment of minority women by their cultures has become the normative space where the state justifies the regulation of certain populations. Phillips (2007) observes that the rationale behind this trend is based on the assumption that minority cultures do not uphold women's human rights. She points out that:

'[C]ulture is now used to deny agency and explain everything minorities do. It more commonly appears in punitive polices designed to stamp out what have been deemed inappropriate or unacceptable practices.'

(Phillips, 2007, p. 8)

In Secure Borders, discursive strategies such as these derive their rationale from the racialised and gendered assumptions that suggest that non-Western cultures are more coercive, and women are less able to exercise agency within them (Kapur, 2005). 
Yet policy on sex trafficking does not emerge in isolation. In Secure Borders, the female trafficked migrant's vulnerability intersects with the state's normative agenda to extend its security capability on border control and immigration law extra-territorially. If the state is to be able to conflate the need to protect the national community and regulate the movement of unwanted populations, then it follows that the UK must have the ability to reconfigure the scope and reach of its regulatory power. Yet this capability in isolation is inadequate. The government must be able to ground its regulatory power in concrete terms (i.e. organized crime gangs' exploitation of vulnerable populations of women, threats to the nation-state from terrorism) in order to give it normative legitimacy both at home and internationally (Benhabib, 2004). Thus, in the period 2002-2006, it is possible to argue that UK strategies to prevent human trafficking 'at source' are based on the understanding that the link between international migration and security are key. Cast in securitised terms, the intensification of state control on human trafficking hinges on 'anxieties about the outside world encroaching upon a vulnerable inside' (McNevin, 2007, p. 657). In the final section of Secure Borders, the Home Office outlines a list of extra-territorial anti-trafficking measures intended to protect the UK from unwanted migrants. These initiatives include:

- UK involvement in overseas projects to stem human trafficking in source countries;

- the involvement of border and immigration authorities and airline personnel in profiling geospecific populations deemed to be vulnerable to traffickers;

- biometric regulation of the mobility of these populations;

- prosecution of traffickers; and

- the protection of victims of trafficking.

In the following section, I turn to the Home Office's 2006 UK Action Plan on Tackling Human Trafficking. More specifically, I want to demonstrate how the Home Office has developed the biopolitical initiatives it set out in Secure Borders. My fundamental aim is to show how these normative interventions provide the state with new spaces in which to reorganize and rescale its power territorially and ideologically. Below, I highlight three contexts that detail the connections between biopolitical regulation of the female trafficked migrant as part of the emergence of new normative geographies. In The Action Plan, the policy interventions are as follows: (I) Prevention of Human Trafficking, (2) Law Enforcement and Prosecution of Traffickers and (3) Protecting Victims of Human Trafficking.

\section{Discourses of securitisation in human trafficking debates in the UK}

In 2006, the Home Office released its Consultation Paper, The Action Plan. The stated purpose of the document was to develop and extend issues identified in Secure Borders concerning human trafficking. The publication of the Consultation Paper coincided with the two hundred year anniversary of the I806 Slave Trade Act that outlawed the slave trade throughout the British empire. The state's attempts to link the nineteenth-century slave trade with modern initiatives on human trafficking are not random. It is the continuation of a political and discursive rendering of British identity where cultural markers, such as justice and human rights, are reframed and absorbed into normative concern with irregular migration and national security (Yuval-Davis et al., 2005). In what follows, I assert that, in 2006, the idiom of the trafficked migrant has become 'both an index of fear and a vehicle for inscribing fear as a political currency and an organising principle in social and political relations' (Huysmans, 2006, p. 6I). I argue that in The Action Plan we have a response to human trafficking, and the racialised and gendered discourses that justify it, that draws on deep normative anxieties about the place of 'Others' in the nation-state. 


\section{Biopolitics: prevention through spatial distance}

One of the key ways that these new normative geographies of securitisation are grounded in The Action Plan is through the state's continued discursive and real deployment of spatial distance to prevent the movement of certain populations into the UK. In The Action Plan we can see how the government's use of spatial distance is not merely symbolic; it has become a biopolitical reality for millions of people that facilitates the state transference of security concerns about immigration onto their mobility (Sullivan, 20I0). In relation to the place of human trafficking within neoliberal governmentality, I argue that the government's use of discourses of vulnerability operate in two interconnected ways. First, they serve to exclude unwanted populations from the national community, and second, they work to discipline the national community in a devolved form of governmentality. This occurs by incorporating the body politic into the job of defending the nation-state, and by using public anxiety to garner a culture of hyper-vigilance about all external threats.

Returning to The Action Plan, it becomes possible to visualise how a number of the UK's extraterritorial anti-trafficking initiatives rescale and devolve responsibility for distancing unwanted migrants onto a variety of actors. The state achieves this not by targeting victims of human trafficking as a threat per se, but by discursively and institutionally connecting trafficking with organised immigration crime and border control issues:

'[H]uman trafficking is a truly appalling crime where people are treated as commodities and traded for profit. It is big business, often controlled by organized crime groups.'

(HMSO, 2006, p. 2)

An important element in the state's justification of its control-orientated initiatives on human trafficking is The Action Plan's discursive reliance on externalising the threat posed by traffickers not to trafficked migrants, but to the national community. In the light of these concerns, The Action Plan asserts that the most appropriate response to this problem is one based on extending the UK's normative influence in anti-trafficking programmes into other jurisdictions. An instructive example of the centrality of spatial distance in the Home Office's reframing of human trafficking as part of a range of security concerns is the government's insistence that:

'[W]e need to continue to undertake work which increases the capacity of law enforcement agencies to deal with trafficking, in source and transit countries, raise awareness amongst people who are vulnerable to the traffickers and improve the situation of the source country to remove some of the push factors which make people fall prey to traffickers.'

(HMSO, 2006, p. 8)

Externalising the problem of human trafficking and organised immigration crime helps to validate The Action Plan's multi-scalar involvement of a number of departments such as the Foreign and Commonwealth Office (FCO), and the Department for International Development (DiFD) in control-orientated and overseas plans against human trafficking. It is not an accident that the vast majority of these initiatives are located in the developing world. Countries in 'the Great Mekong region which includes part of Cambodia, China, Laos, Thailand and Vietnam' (HMSO, 2006, p. 8) constitute primary source countries for human trafficking. Elsewhere in The Action Plan, the Home Office reveals that the FCO has responsibility for anti-trafficking projects 'in Bangladesh, India and Pakistan' (HMSO, 2006, p. 9). Closer to home and at the edges of EU territory, The Action Plan draws our attention to its plans:

' $[\mathrm{T}] \mathrm{o}$ build capacity in source and transit countries the FCO...supports programmes in Albania ... [and] in Bosnia.'

(HMSO, 2006, p. 9)

The Home Office's overseas anti-trafficking programmes resonate with a contemporary figuring of Foucault's work on biopolitical power. In the context of human trafficking, biopolitical regulation of populations of women is a technique of a rescaled 'strategic field of power' (Foucault, 2009, p. 388). 
To ground these control-orientated geographies, I focus on the 'field of micro-powers' (Foucault, 2009, p. 38I) that ensure spatial distance between bodies and territory that constitute a significant part of the UK's anti-trafficking programme. One of the most visible of the devolved forms of spatial distancing is the Home Office's attempts to gather information about suspected trafficked migrants and traffickers. Based on this data retrieval, the biopolitics of governmentality comes into sharp relief. A key element of the biopolitics of this process is how the state incorporates a series of actors into the exclusion process. Visa-issuing personnel are the embodiment of devolved neoliberal governmentality at its most dispersed and flexible, ready to adapt to the needs of the vulnerable nation-state when required. Consider the following proposal:

'[W]e will raise awareness of trafficking amongst our visa-issuing posts overseas so that suspected traffickers, and their potential victims, are not issued with visas to travel to the UK.'

(HMSO, 2006, p. Io)

While the UK government is quick to point out that these regulatory measures are designed to protect all trafficked migrants, on balance, the proliferation of human trafficking is taken as 'a sign of the importance of security framing in the area of immigration' (Huysmans, 2006, p. 68).

A second, and perhaps more troubling aspect on a human rights level is the Home Office's insidious use of British and other airline personnel to check migrant's documents. The Home Office justifies its use of this technique in relation to human trafficking in its 2002 Secure Borders. The Action Plan develops these connections, and demonstrates how airlines and their employees are now part of the UK's frontline strategy to stop trafficking at source. This move is further evidence of the rescaling of responsibility for security across the UK and beyond. The form of spatial distancing is apparent in how the Home Office frames its measures:

'We will raise awareness of trafficking amongst Airline Liaison Officers in source and transit countries and consider ways in which we could raise awareness amongst airline carriers.'

(HMSO, 2006, p. I0)

Yet the fact of the matter is that the Immigration (Carriers' Liability) Act of $1987^{2}$ requires all airlines and their employees to monitor passengers, and to report suspected trafficked migrants to the relevant immigration authorities. Failure to adhere to the letter and spirit of the law can result in legal action.

By incorporating various actors into the processes of gathering data and tracking the movements of female trafficked migrants under the auspices of protecting them from exploitation, the state extends its power extra-territorially. Knowledge about targeted populations also helps to perpetuate xenophobic and gendered discourse and practice, especially among airline personnel who adopt stereotypes of geo-specific populations and use this information to impede their mobility (Sullivan, 20I0). The state's attempts to gather information about vulnerable female trafficked migrants helps to create and sustain the political 'reality' that perpetuates the need for increased securitisation in the first instance. Huysmans (2006) observes that the state's technological and policy responses to issues such as human trafficking often pre-date events, and often act to structure how the state categorises migrants, i.e. as a terrorist, security threat or illegal migrant. Operating through a security framework, the vulnerable female trafficked migrant becomes the

2 Immigration (Carriers' Liability Prescribed Sum) Order (S.I. I99I No.I497). The United Kingdom, along with Germany and Belgium, followed the policy of traditional countries of immigration, such as the United States, Canada and Australia, and introduced legislation which provides for the imposition of fines on carriers for bringing in passengers with incorrect papers (Cruz, I994). The Immigration (Carriers' Liability) Act I987

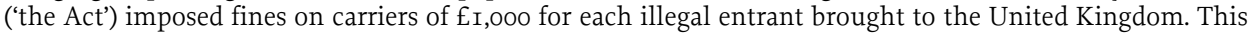
fine was doubled in August I99I and two years later extended to cover passengers without transit visas where these were required (Nicholson, I997). 
embodiment of a set of normative practices that justify the UK's extra-territorial activities and its use of technology such as biometrics. Having established how The Action Plan uses spatial distance to link human trafficking to broader security concerns, I turn my attention to how this discourse is put to work to justify normative discourse and practice.

\section{Biopolitics through investigation, law enforcement and prosecution}

The preceding section outlines how The Action Plan reframes human trafficking as part of processes of spatial distancing between 'us' and 'them'. It is also essential to take into account how this discursive framing 'places the regulation of migration in an institutional framework that deals with the protection of internal security' (Huysmans, 2006, p. 68). Consequently, The Action Plan situates its law enforcement response to trafficking to include:

'[R]aising awareness of trafficking issues among the police, developing appropriate resources for frontline staff and carrying out a review of police training on this issue.' (HMSO, 2006, p. 3)

Returning to Foucault's (2003) theorisation of biopolitics to include the scale of the UK government's law and order response to trafficking helps to strengthen the spatial aspect of my analysis. The perception that trafficking is primarily a law and order concern justifies a state control-oriented response (Huysmans, 2006) as a normative response that keeps criminals from Britain's shores. Consider the following:

'The UK is determined to deal with the criminals who are responsible for this illegal trade in people. We have already criminalised trafficking... The UK places great emphasis on tackling trafficking on the ground in partnership with law enforcement and intelligence agencies both in the UK and overseas.'

(HMSO, 2006, p. II)

It is clear from this quotation that the state recognises the importance of spatial distance. But this section of The Action Plan is framed in terms of impeding the activities of organised crime gangs. All discussion of the vulnerable trafficked migrant tends toward the effects of organised crime on the national community. It eschews the impact of increased securitisation on trafficked migrants' mobility, and their right to migrate (FitzGerald, 2009). Thus, the state's ability to map discourses of vulnerability onto the needs of the national community is another key space of biopolitical governance. It at once prescribes and exemplifies a normative biopolitics that conceives of securitisation both as an economic matter and as a crucial element in managing populations.

Importantly, the Home Office introduces the reader to a variety of control-orientated task forces, such as the Serious Organized Crime Agency (SOCA), a 'single, specialist organisation with a harm reduction focus' (HMSO, 2006, p. II). The Home Office constructs a hegemonic narrative around SOCA that justifies its methods. It is clear from the outset that SOCA, and its partners, are focused more on domestic space security than on protecting the vulnerable trafficked migrant per se. The active force here is the state's ability to garner public anxiety about the impacts of organised crime and immigration on the national economy. Positioned as such, The Action Plan reveals how the state uses the specific 'harms caused to the UK and UK citizens by organized criminal activity, costs of which are estimated at over £2oobn a year' (HMSO, 2006, p. II) to justify its interventions.

If the biopolitical discourses of population, the economy and security unite in the Home Office's law and order response to trafficking, so does a preoccupation with maintaining spatial distance between 'here' and 'there'. It is in this context that The Action Plan situates Reflex, a 'practical multiagency task force to combat organised crime' (HMSO, 2006, p. I3). While Reflex targets human trafficking, however, it soon becomes clear that the task force is dedicated to tackling organised 
immigration crime. Evidence of the importance of spatial distance and the state's extra-territorial activities as a tactic of securitisation is clear when the Home Office insists that Reflex's extraterritorial interventions in:

'Romania is another example of a successful overseas project... the UK and Romania agreed to establish a central intelligence unit based in Bucharest to focus on organized crime originating in and transiting through Romania.'

(HMSO, 2006, p. I4)

The primacy of immigration and border control is evidenced in The Action Plan through the following statement:

'Under Reflex considerable work has also been undertaken in Serbia and Montenegro along with work in Bosnia and Herzegovina to establish a consistent regional approach in respect of border control management.'

(HMSO, 2006, p. I4)

What is particularly interesting here is the absence of any real discussion of the needs of the vulnerable female trafficked migrant. In short, the notion of the vulnerable nation-state eclipses the needs of the female trafficked migrant as a central normative discourse. This discursive strategy reveals the driving force behind The Action Plan: the need for spatial distance between the UK and unwanted migrant populations. In fact, in this section of the document the female trafficked migrant comes to occupy another critically important discursive space, namely she embodies the need for heightened security due to 'the scalar transgressions made available in an ever more globalised world' (Legg, 2009, p. 242). In stressing this important discursive shift, it becomes possible to argue that increased internationalism does not pose a threat to national sovereignty. Rather, attempts to co-ordinate normative responses to human trafficking illustrate the precise terrain of new and emerging geographies of the neoliberal state (McNevin, 2007). Viewed through a spatial lens, the geography of the neoliberal state does not constitute the state losing control of its territory. Returning to the methodological framework suggested earlier in this article, extra-territorial co-operation on trafficking should not be mistaken for a process of normative homogenisation across Western jurisdictions, and further evidence of the unbundling of the sovereignty of the nation-state. In fact, cross-jurisdictional co-operation on trafficking, I want to argue, is producing new state-centred normative arrangements that extend the nation-state's capacity for territorial and biopolitical control of the nation-state.

In what follows, I turn my focus on how the UK government attempts to use spatial distance to instigate a series of protective measures for victims of trafficking. In mapping the biopolitics of this embodied vulnerability, I argue that this act of visualising problematic populations does other important work; it acts to justify the Home Office's use of racialised and gendered discourse in processes that we do not always recognise as exclusionary. This occurs, in part, because the state disguises its tactics in its response to the female trafficked migrant as a site of humanitarian protection.

\section{Biopolitics through protection and assistance to victims of trafficking}

We can see this strategy continued in the final section of The Action Plan. Part of the design of this normative intervention is to hide the function of biopolitics and the surveillance gaze of the state. The body of the vulnerable female trafficked migrant, who may or may not cross borders to work in the sex industry, is the embodied space that renders the need for securitisation more visible (Askola, 2008). The way in which the UK government uses women's bodies, as another site to defend the national community, makes clear the biopolitical practices of the state (FitzGerald, 2008). The Home Office's decision to protect and offer assistance to the victims of trafficking is really a decision to include or expel geospecific populations from the national community (Sullivan, 20I0). 
The process by which The Action Plan establishes the state as the 'protector' who will 'rescue' vulnerable female trafficked migrants from the clutches of organised crime gangs, is positioned and expressed in the intersection of categories of gender, race, ethnicity and sexuality (Kapur, 2005). It is clear that the bureaucracies of protection in the UK retain a discursive connection between human trafficking, trans-border sex work and women (Munro, 2005). This comes into sharp relief when we consider the kinds of victims of trafficking who will receive state protection. One does not need to look too far to see how this discursive strategy diffuses through The Action Plan. The Home Office uses trans-border sex work to direct our attention as follows:

'As part of a wider coordinated strategy on prostitution we will work to reduce the demand for women and children trafficked for the purposes of prostitution.' (HMSO, 2006, p. I0)

The Action Plan rationalises its focus on prostitution by arguing that women, in particular, are more vulnerable to traffickers in source countries because:

'[M]ore is known about the recruitment of women and girls for the sex trade. Traffickers use a variety of methods to recruit females into the vice trade. Most involve some form of deception and exploit the lack of opportunities open to women in source countries.' (HMSO, 2006, p. I5)

It is important to place racialised and gendered vulnerabilities within their sociospatial context. Phillips (2007) argues that in the UK the state's attempt to stamp out abuses of women from minority cultures has become a biopolitical bordering process. This is an important addition to Foucault's (2003) theorisation of sexuality as linked to debates about the biopolitics of belonging to the nationstate. The Home Office makes the argument that:

'Traffickers ... usually trick their victims into travelling with them to the UK with promises of legitimate employment here. But instead, the victims find themselves trapped in abusive and exploitative situations, working as forced labour or working in the sex trade.' (HMSO, 2006, p. I5)

This framing of the female trafficked migrant invokes stereotypes of non-Western women as naive and hapless to the vagaries of organised crime gangs (Kapur, 2005).

With this sense of purpose, the Home Office proceeds to use discourses of female vulnerability to justify a series of protection programmes. This tendency is articulated in The Action Plan by linking initiatives to assist 'adult victims of trafficking for the purposes of sexual exploitation' (HMSO, 2006, p. I5). This objective is linked to the state-sponsored Poppy project. This scheme provides shelter and basic care on a short-term basis to 'women who have been brought to the UK to work as prostitutes' (HMSO, 2006, p. I5). However noble this programme may be, I argue that the framing of this humanitarian assistance is situated in deeper concerns about securitisation and removing unwanted migrants from the UK (Yuval-Davis et al., 2005).

The securitisation of trafficking as a normative geography is revealed in the details. According to The Action Plan, the Poppy project will only offer long-term assistance to women 'who actively assist the authorities in gathering information about the traffickers and taking action against them' (HMSO, 2006, p. I5). Returning to Foucault's (2009) theory of biopolitics, it is possible to argue that projects such as the Poppy project act as spaces of 'population management' (Legg, 2009, p. 3) by segregating trafficked migrants from the national community. Projects such as these segregate 'good' trafficked migrants from 'bad' ones. Furthermore, by insisting that the state will only help those victims who help the state, this, in effect, corresponds to technologies of governmentality that work on and through the body. Such calculative forms of governmentality require the trafficked migrant to be a passive body that will comply with the needs of the state (Scoular, 2004). The process by which the state attempts to create a zone of exclusion around 'appropriate' victims, who belong in the UK, corresponds to the biopolitics of state-formation. 
The government's plans reveal how the protection of vulnerable women involves a system of race and gender profiling. The state's strategic priority is 'to identify victims of trafficking at the earliest opportunity' (HMSO, 2006, p. I6). Under this rubric, awareness and education for 'all immigration staff at our borders' (p. I6) is another form of spatial distancing. Deflecting public attention onto the perceived need to maintain distinct boundaries organised around 'real' victims of trafficking reinforces stereotypes of non-Western women 'and ... render[s] cross border movements, especially by poor or working class women, suspect' (Kapur, 2005, p. I47). One of the most significant ways that the Home Office enforces techniques of spatial distance is to provide immigration staff with 'profiles of trafficking victims to aid early identification and quick referral to appropriate support' (HMSO, 2006, p. I8).

In the context of The Action Plan, immigration and border control staff constitute another embodied space of devolved biopolitical regulation whose primary task is 'to disrupt the flows of those who do not qualify' to be here (HMSO, 2006, p. I6). Pursuing this line of argument, another issue at stake might be developed here. This concerns The Action Plan's discussion of schemes to assist with the removal of trafficked migrants from the UK. Exclusion here concerns the physical removal and 'reintegration supports and employment training for victims of trafficking' (HMSO, 2006, p, 9). The development of such exclusionary tactics incorporates state 'assistance to victims who wish to return home' (HMSO, 2006, p. I8). Thus the UK's reconfigured form of biopolitical regulation may be understood to be located in the body and behaviours of the self-regulating female victim. This body will comply with the needs of vulnerable nation-state, and leave the UK voluntarily.

'We recognise that it is important to provide support and assistance to victims of trafficking who wish to return home. Victims of trafficking will continue to use the current assisted voluntary return programmes.'

(HMSO, 2006, p. I8)

This is, it seems to me, precisely the normative process today that explains, in part, the surge of interest in regulating the mobility of geospecific populations that I began by noting.

\section{The mobility/security nexus}

Recent normative responses to human trafficking illustrate how the state attempts to reframe human trafficking as part of a security continuum. I assert that strategies to uphold the 'right to protect' the nation-state through tactics of exclusion requires serious further consideration. What kind of right is this? Most importantly for my concerns, we need more interdisciplinary work on how the neoliberal state frames the notion of female vulnerability in new and emerging normative geographies. Therefore, my principal aim in this paper has been to attempt to contribute to conversations that may generate radical insights and effects on the spatiality of law.

The ways in which the idiom of the female trafficked migrant is representative of those chaotic populations who transcend national borders, illustrates how the regulation of mobility is in part neoliberal reconfiguration of state power. Vulnerability in this context refers to a set of techniques and procedures used by state parties to identify perceived threats to the national community. Thus, I have attempted to illustrate how the discursive and institutional reframing of vulnerable migrant populations has provided multiple spaces where the neoliberal state can engage in biopolitical regulation of the body politic. For, as I argued above, this tactic of governmentality is marked spatially by the state's continued and ever-evolving efforts to maintain spatial distance between receiving and migrant populations. The latter is particularly important, given that one of the central paradoxes of state policy on human trafficking is the charge that spatial distancing has become a means to reconfigure power extra-territorially. Viewed through a spatial lens, I argue that 
the geography of the neoliberal state does not constitute the state loosing control of its territory. Returning to the methodological framework suggested earlier in this article, this extra-territorial regulation should not be mistaken for a process of normative homogenisation across Western jurisdictions, and further evidence of the unbundling of the sovereignty of the nation-state. In fact, cross-jurisdictional co-operation on human trafficking is producing new state-centred normative arrangements that require new engaged and considered analysis.

\section{References}

ALCOFF, Linda (I988) 'Cultural Feminism versus Post-Structuralism: The Identity Crisis in Feminist

Theory', Signs: Journal of Women in Culture and Society I3: 405-436.

AlCoff, Linda (I994) 'A Philosophical Dialogue with "Dialogue with the Other”,' Gender-NatureCulture, (vol): 5-22.

ASKola, Heli (2008) Legal Responses to Trafficking in Women for Sexual Exploitation in the European Union. Oxford: Hart Publishing.

Augustin, Laura (2005) 'Migrants in the Mistress's House: Other Voices in the "Trafficking” Debate',

Social Politics, I 2: 96-I I 7 .

Augustin, Laura (2007) Sex at the Margins: Migration, Labour Markets and the Rescue Industry. London:

Zed Books.

BARRY, Kathleen (I979) Female Sexual Slavery. New York: Avon.

BARRY, Kathleen (I995) The Prostitution of Sexuality. New York: New York University Press.

Beasley, Chris (I999) What is Feminism Anyway? Understanding Contemporary Feminist Thought.

London: Allen and Unwin.

Benhabib, Seyla (2004) The Rights of Others: Aliens, Residents and Citizens. Cambridge: Cambridge

University Press.

вотtomley, Ann and conaghan, Joanne (eds) (1993) Feminist Theory and Legal Strategy. Oxford: Blackwell.

BRidgeman, Jo and millins, Sue (eds) (I995) Law and Body Politics. Aldershot: Dartmouth.

Buonfino, Alessandra (2004) 'Between Unity and Plurality: The Politicisation and Securitisation of

the Discourse of Immigration in Europe', New Political Science 26: 23-44.

ButLer, Judith (2005) Giving an Account of Oneself. New York: Fordham University Press.

CHARLESWorth, Hillary and CHInkin, Christine (2000) The Boundaries of International Law: A Feminist

Analysis. Manchester: University of Manchester Press.

COOPER, Davina (2004) Challenging Diversity: Rethinking Equality and the Value of Difference. Cambridge:

Cambridge University Press.

CORnell, Drucilla (I998) At the Heart of Freedom: Feminism, Sex and Equality. Princeton: Princeton

University Press.

CRENSHAW, Kimberlé (I994) 'Mapping the Margins: Intersectionality, Identity Politics, and Violence

Against Women' in Martha Fineman and Roxanne Mykitiuk (eds) The Public Nature of Private

Violence. New York: Routledge, 93-I I 8.

Crenshaw, Kimberlé, gotanda, Neil, and Peller, Garry (eds) (i995) Critical Race Theory: The Key

Writings that Formed the Movement. New York: New York University Press.

CRUZ, Antonio (I994) Carriers Liability in the Member States of the European Union. Brussels: Churches

Commission for Migrants in Europe, Paper 17.

cunningham, David (2008) 'Spacing Abstraction: Capitalism, Law and the Metropolis', Griffith Law

Review Special Issue: Invisible Laws, Invisible Cities, I7: 454-69.

doezema, Jo (2005) 'Now You See Her, Now You Don't: Sex Workers at the UN Trafficking Protocol

Negotiation', Social \& Legal Studies I4: 6I-89. 
Dustin, Moira and Phillips, Anne (2008) 'Whose Agenda is it? Abuses of Women of "Culture" in

Britain', Ethnicities 8: 405-424.

eisenstein, Zillah (2004) Against Empire: Feminisms, Racism and the West. Melbourne: Spinifex Press.

fineman, Martha (2008) 'The Vulnerable Subject: Anchoring Equality in the Human Condition',

Yale Journal of Law and Feminism 20: 8-40.

fineman Martha and thomadsen, Nancy (eds) (I99i) At The Boundaries of Law: Feminism and Legal

Theory. New York: Routledge.

FitzGerald, Sharron (2008) 'Putting Trafficking on the Map: The Geography of Feminist Complicity',

in Vanessa Munro and Mariana Della Giusta (eds) Demanding Sex: Critical Reflections on the

Regulation of Prostitution. Aldershot: Ashgate, 99-I 20.

FITZGERALD, Sharron (2009) 'The Female Diaspora: Interrogating the Female Trafficked Migrant', in

Amita Dhanda and Archana Parashar (eds) Decolonisation of Legal Knowledge. New Delhi:

Routledge, I27-5I.

FLETCHER, Ruth (2005) 'Reproducing Irishness: Race, Gender and Abortion Law', Canadian Journal of Women and the Law I7: 365-404.

foucault, Michel (2003) Society Must Be Defended: Lectures at the Collège de France 1975-1976.

London: Penguin Books.

Foucault, Michel (2009) Security, Territory, Population: Lectures at the College de France 1977-1978.

New York: Palgrave Macmillan.

FRASER, Nancy (2007) Scales of Justice: Reimagining Political Space in a Globalizing World. Oxford: Polity

Press.

GILBERT, Emily (2007) 'Leaky Borders and Solid Citizens: Governing Security, Prosperity and Quality

of Life in a North American Partnership', Antipode 39: 77-98.

GOODEY, Jo (2002) 'Whose Insecurity? Organised Crime, its Victims and the EU', in A. Crawford (ed.)

Crime, Insecurity and Safety in the New Governance. Cullompton: Willan Publishing, I35-58.

GRABHAM, Emily and hUnTER, Rosemary (2008) 'Encountering Human Rights: Gender/Sexuality,

Activism and the Promise of Law', Feminist Legal Studies, I6(I): I-7.

hannah, Matthew (200I) 'Sampling and the Politics of Representation in the US Census 2000',

Annals of the Association of American Geographers I9: 5I5-34.

Henderson, Tony (I999) Disorderly Women in Eighteenth-Century London: Prostitution and Control in the

Metropolis I730-I830. London: Pearson.

HOME OFFICE (2002) Secure Borders, Safe Haven: Integration and Diversity in Modern Britain. London:

HMSO.

HOME OFFICE AND SCOTTISH EXecutive (2006) UK Action Plan on Tackling Human Trafficking. London:

HMSO.

HONIG, Bonnie (200I) Democracy and the Foreigner. Princeton: Princeton University Press.

hubbard, Phillip, matthews, Roger and scoular, Jane (2008) 'Regulating Sex Work in the EU:

Prostitute Women and the New Spaces of Exclusion', Gender, Place and Culture I5(2): I37-52.

Hughes, Donna (2002) Trafficking for Sexual Exploitation: The Case of the Russian Federation. Geneva:

IOM.

huYsmans, Jef (2006) The Politics of Insecurity: Fear, Migration and Asylum in the EU. London: Routledge. hyndman, Jennifer (2000) Managing Displacement: Refugees and the Politics of Humanitarianism.

Minneapolis: University of Minnesota Press.

KAPUR, Ratna (2005) Erotic Justice: Law and the New Politics of Postcolonialism. London: Glasshouse Press. Kempadoo, Kamala (ed.) (I999) Sun, Sex, and Gold: Tourism and Sex Work in the Caribbean. Lanham, MD: Rowman and Littlefield.

Kofman, Eleonore (2005) 'Citizenship, Migration and the Reassertion of National Identity', Citizenship

Studies 9: 453-67. 
KUMAR, Satish (2005) “'Oriental Sore” or "Public Nuisance”: The Regulation of Prostitution in Colonial India, I865-1889', in Lindsey Proudfoot and Mike Roche (eds) Displacing Empire: Renegotiating British Colonial Geographies. Aldershot: Ashgate, I55-73.

LACEY, Nicola (1998) Unspeakable Subjects: Feminist Essays in Legal and Social Theory. Oxford: Hart Publishing.

LEGG, Stephen (2005) 'Foucault's Population Geographies: Classification, Biopolitics and Governmental Spaces', Population, Space and Place I I: 137-56.

LEGG, Stephen (2009) 'Of Scales, Networks and Assemblages: The League of Nations Apparatus and the Scalar Sovereignty of the Government of India', Transactions of the Institute of British Geographers NS 34(2): 234-53.

MACKInNon, Margaret (I989) Towards a Feminist Theory of the State. Cambridge, MA: Harvard University Press.

mackinnon, Margaret (2006) Are Women Human and Other International Dialogues. Cambridge, MA: Harvard University Press.

mCNEvin, Anne (2007) 'Irregular Migrants, Neoliberal Geographies and Spatial Frontiers of "The Political”, Review of International Studies 33: 655-74.

miller, Alice (2004) 'Sexuality, Violence Against Women, and Human Rights: Women Make

Demands and Ladies Get Protection', Health and Human Rights I7: I6-47.

Moutz, Alison (2004) 'Embodying the Nation-State: Canada's Response to Human Smuggling', Political

Geography 23: 323-45.

munro, Vanessa (2005) 'A Tale of Two Servitudes: A Domestic Response to Trafficking of Women

for Prostitution in the UK and Australia', Social and Legal Studies I4: 9I-I I4.

munro, Vanessa and della giusta, Marina (eds) (2008) Critical Perspectives on Prostitution. Aldershot: Ashgate.

NAGAR, Richa, LAWSON, Victoria, MCDOWELL, Linda and HANSON, Susan (2002) 'Locating Globalisation:

Feminist (Re)Readings of the Subjects and Spaces of Globalisation', Economic Geography 78(3):

$257-84$.

Nicholson, Frances (1997) 'Implementation of the Immigration (Carrier Liability) Act 1987:

Privatising Immigration Functions at the Expense of International Obligations', International and Comparative Law Quarterly 46: 586-634.

nussbaum, Martha (1999) Sex and Social Justice. Oxford: Oxford University Press.

pateman, Carol (i988) The Sexual Contract. Oxford: Polity Press.

PERrons, Dianne (2004) Globalization and Social Change. London: Routledge.

PHILLIPS, Anne (2007) Multiculturalism without Culture. Princeton: Princeton University Press.

PHILlips, Richard (2006) Sex, Politics and Empire: A Postcolonial Geography. Manchester: Manchester

University Press.

PHILo, Chris (2000) 'The Birth of the Clinic: An Unknown Work of Medical Geography', Area 32:

I I-I9.

RIAÑo, Yvonne and WastL-WaLter, Doris (2006) 'Immigration Policies, State Discourses on Foreigners, and the Politics of Identity in Switzerland', Environment and Planning A 38: 1693-7I 3.

ROSE, Nikolas and osborne, Thomas (2004) 'Spatial Phenomenotechnic: Making Space with Charles

Booth and Patrick Geddes', Environment and Planning D: Society and Space 22: 209-228.

Russell, Jim (2005) 'Rethinking Post-National Citizenship: The Relationship between State Territory and International Human Rights Law', Space and Polity 9(I): 29-39.

SAMERS, Michael (2000) 'An Emerging Geopolitics of "Illegal" Immigration in the European

Union', European Journal of Migration and Law 6: 27-45.

SANDERS, Teela and CAMPBELl, Rosie (2007) 'Designing Out Vulnerability, Building Respect: Violence,

Safety and Sex Work Policy', British Journal of Sociology I: I-I8. 
SCHUSTER, Lisa and solomos, John (2004) 'Race, Immigration and Asylum: New Labour's Agenda and its Consequences', Ethnicities 4: 267-87.

Scoular, Jane (2004) 'The "Subject" of Prostitution: Interpreting the Discursive, Symbolic and Material Position of Sex/Work in Feminist Theory', Feminist Theory 5: 343-55.

SCOUlAR, Jane and o'NEILl, Maggie (2007) 'Regulating Prostitution: Social Inclusion, Responsibilization and the Politics of Prostitution Reform', British Journal of Criminology, 47: 764-78.

SILVEY, Rachel (2006) 'Geographies of Gender and Migration: Spatialising Social Difference', International Migration Review, 40: 64-8I.

SMART, Carol (1989) Feminism and the Power of Law. London: Routledge.

SмIтH, Dorothy (I999) Writing the Social: Critique, Theory and Investigations. Toronto: University of Toronto Press.

staeheli, Lynn, kofman, Eleonore and Peake, Linda J. (eds) (2004) Mapping Women, Making Politics: Feminist Perspectives on Political Geography. London: Routledge.

suluivan, Barbara (2003) 'Trafficking in Women', International Feminist Journal of Politics, 5(I), 67-9I. sullivan, Barbara (2010) 'Trafficking in Human Beings', in Laura, Sheppard (ed.) Gender Matters in Global Politics. London: Routledge, 89-102.

WALLACH-SCOTT, Joan (I999) Gender and the Politics of History. New York: Columbia University Press. WALton-roberts, Margaret (2004), 'Rescaling Citizenship: Gendering Canadian Immigration Policy', Political Geography 23: 267-8I.

young, Iris Marion (I990) Justice and the Politics of Difference. Princeton: Princeton University Press.

young, Jock (2003) 'To These Wet and Windy Shores: Recent Immigration Policy in the UK', Punishment Society 5: 449-62.

yuval-Davis, Nira, anthias, Floya and kofman, Eleonore (2005) 'Secure Border and Safe Haven and the Gendered Politics of Belonging: Beyond Social Cohesion', Ethnic and Racial Studies 28(3): 5I $3-35$. 